\title{
PERANAN LEMBAGA KEAGAMAAN AL-IRSYAD DALAM PENDIDIKAN DI INDONESIA
}

\author{
Muh. Dahlan Thalib \\ Email: thalib.dahlan@yahoo.co.id \\ IAIN Parepare
}

\begin{abstract}
The leaders of the national movement with full consciousness want to change the future of the Indonesian nation, so the agenda of the struggle is to organize national education. One association concerning the advancement of education is the association of al-Irsyad, a religious institution devoting its attention to the field of education marked by the official opening of Madrasahs from primary to middle. Al-Irsyad managed to mobilize the intelligence of the Indonesian nation in the field of education is not limited only among the descendants of Arab Muslims but also citizens muslim Indonesia (native population). The main point of instruction in the madrasah is to give priority to Arabic so that students can understand the teachings of Islam well. Al-Irsyad also strives to restore society to the correct purification of Islamic teachings so that all forms of life activities and life of the people is always based on Al-Qur'an and Hadith which is more emphasis on aqidah ketauhidan in order to realize the Muslim person and the Islamic community to keridhoan Allah swt.
\end{abstract}

Keywords: Al-Irsyad institution, education and religion.

\begin{abstract}
ABSTRAK
Para pemimpin gerakan nasional dengan kesadaran penuh ingin mengubah masa depan bangsa Indonesia, sehingga agenda perjuangannya adalah menyelenggarakan pendidikan nasional. Satu asosiasi mengenai kemajuan pendidikan adalah asosiasi al-Irsyad, sebuah lembaga keagamaan yang mencurahkan perhatiannya pada bidang pendidikan yang ditandai dengan pembukaan resmi Madrasah dari tingkat dasar hingga menengah. Al-Irsyad berhasil memobilisasi kecerdasan bangsa Indonesia di bidang pendidikan tidak terbatas hanya di antara keturunan Muslim Arab tetapi juga warga muslim Indonesia (penduduk asli). Poin utama pengajaran di madrasah adalah memberikan prioritas pada bahasa Arab sehingga siswa dapat memahami ajaran Islam dengan baik. Al-Irsyad juga berupaya mengembalikan masyarakat ke
\end{abstract}


pemurnian ajaran Islam yang benar sehingga segala bentuk aktivitas kehidupan dan kehidupan masyarakat selalu didasarkan pada Al-Qur'an dan Hadits yang lebih menekankan pada aqidah ketauhidan dalam rangka mewujudkan Orang muslim dan komunitas Islam untuk keridhoan Allah swt.

Kata kunci: institusi Al-Irsyad, pendidikan dan agama.

\section{PENDAHULUAN}

\section{Latar Belakang Masalah}

Sebagaimana diketahui bahwa penaklukan bangsa barat atas dunia timur dimulai dengan jalan perdagangan kemudian dengan kekuatan militer, tak terkecuali bangsa Indonesia yang telah merasakan tindakan semena-mena, sehingga atas kesadaran masyarakat sendiri mulai mengadakan perlawanan terhadap penjajah.

Dengan melihat kondisi bangsa Indonesia yang makin hari makin porakporanda kehidupannya, maka para pemimpin Islam dan pemimpin Pergerakan Nasional dengan kesadaran penuh ingin mengubah masa depan bangsa Indonesia, sehingga agenda perjuangannya adalah menyelenggaraan pendidikan secara nasional.

Gerakan pembaharuan dalam Islam yang lahir dari Timur Tengah telah memberikan pengaruh besar kepada gerakan kebangkitan Islam di Indonesia yang bermula dari pembaharuan pemikiran dan Pendidikan Islam di Minangkabau yang disusul oleh pembaharuan pendidikan yang dilakukan oleh masyarakat Arab di Indonesia. ${ }^{1}$ Oleh kerena pendidikan merupakan salah satu perhatian sentral masyarakat Islam, yang sejak awal perkembangan Islam, karenanya umat Islam mendirikan beberapa lembaga organisasi Islam di Indonesia.

Lahirnya beberapa organisasi Islam lebih banyak karena didorong oleh mulai tumbuhnya sikap patriotisme dan rasa nasionalisme serta sebagai respon terhadap kepincangan-kepincangan yang ada dikalangan masyarakat Indonesia pada akhir abad ke 19 yang mengalami kemunduruan total sebagai eksplotasi politik pemerintah kolonial Belanda ${ }^{2}$.

Salah satu organisasi atau perhimpunan Islam pada waktu itu adalah Jami'at Khair, dengan melalui beberapa guru yang didatangkan dari Timur

\footnotetext{
${ }^{1}$ Badri Yatim, Sejarah Peradaban Islam, Dirasah Islamiyah II, Ed, (Cet II; Jakarta : PT. Raja Grafindo Persada, 2000), h.257-258

${ }^{2}$ Zuhairini, dkk, Sejarah pendidikan Islam, Ed. 1; (Cet. 3,Jakarta : Bumi Aksara, 1992), h. 157
} 
Tengah khususnya dari Arab Saudi termasuk diantaranya adalah Syaikh Ahmad Surkati ${ }^{3}$. yang kemudian memisahkan diri dari jami'at Khair, akibat timbulnya perbedaan pendapat mengenai boleh tidaknya dilaksanakan perkawinan yang tidak sekufu (sepadan), dengan adanya perbedaan itu lahirlah perhimpunan baru yaitu Al-Irsyad.

\section{Rumusan Masalah}

Berdasarkan uraian latar belakang diatas, maka penulis menyusun dua masalah yaitu :

1. Bagaimana latar belakang berdirinya Al-Irsyad ?

2. Bagaimana peranan pembaharuan lembaga kelembagaan Al-Irsyad dalam pendidikan di Indonesia?

\section{PEMBAHASAN}

\section{Latar Belakang lahirnya Al-Irsyad ${ }^{4}$}

Pada bulan Rabul Awwal 1329 (bulan Maret 1911 M) datanglah missi pengajar pertama dari Mekkah untuk memperkuat staf pengajar pada sekolah-sekolah Jami'at Khair, mereka adalah Syaikh Ahmad Assoorkattiy Al-Anshary ${ }^{5}$. seorang alim yang terkenal dalam Islam, beberapa tahun kemudian meninggalkan Jamiat Khair tepatnya awal tahun $1914^{6}$ dan mendirikan gerakan Agama bernama Al-Islah Wal Irsyad dengan haluan mengadakan pembaharuan dalam Islam (reformisme), perkumpulan tersebut dikenal Al-Irsyad yang terdiri dari golongan-golongan Arab yang bukan Golongan Alawi.

\footnotetext{
${ }^{3}$ Nama lengkapnya adalah Ahmad bin Muhammad bin Muhammad bin Muhammad bin Muhammad Assoorkattiy Al-Khazrajiy Al-Anshary, lahir di Pulau Arqu Dunggulah Sudan, pada tahun 1292 H (1874 M), Dunggula ketika itu masih termasuk wilayah Mesir. Ayahnya adalah Muhammad, ia seorang ulama besar, keturunan Khazraj dari qabilah Al-Jawaabirah, lewat perantaraan Syaikh Muhammad bin Yusuf al-Khayyath dan Syaikh Husain bin Muhammad Alhabsyi, dua syikh ini adalah pengurus jemaah haji yang datang secara kontinyu ke Indonesia, meminta Ahmad Surkati (panggilan tersohor di Indonesia) menjadi guru pada Jami'at Khair di Indoonesia. Lihat H. Hussein Badjerei, Al- Irsyad Mengisi Sejarah Bangsa, (Cet.I;Jakarta : Badan Penerbit Presto Prima Utama, 1996), h. 34-35

${ }^{4}$ Al-Irsyad adalah organisasi (perhimpunan) orang Arab yang bukan golongan sayyid, lahir dari prakrsa utama Syaik Ahmad Surkati sebagai suatu gerakan keagamaan yang murni, dibantu oleh Syaikh Umar Manggus kapten orang-orang Arab di Jakarta, Saleh bin Ubeid, Said bin Salim Masjhabi, Salim bin Umar Balfas, Abdullah Harharah dan Umar bin Saleh bin Nahdi, Lihat Deliar Noer, Gerakan Moderen Islam di Indonesia 1900-1942, Ed.2, (Jakarta : LP3ES, 1982), h. 73

${ }^{5}$ Liahat Hussein Badjerei, Op.Cit, h.27

${ }^{6}$ Ibid, h. 32
} 
Al-Irsyad adalah pecahan dari organisasi Jami'at Khair, yang lahir akibat terjadinya suatu perpecahan antara golongan ningrat Arab (sayyid) dengan golongan Arab yang demokratis (syaikh), Ketegangan antara golongan sayyid dengan golongan bukan sayyid di Indonesia ketika fatwa yang dikeluarkan oleh Ahmad Surkati di Solo sebagaiman fatwa yang dikeluarkan Rasyid Ridha dari majalah Al-Manar kairo, yang mengemukakan bahwa perkawinan antara seorang Islam bukan sayyid dengan syarifah adalah jaiz ${ }^{7}$

Menurut Steenbrink, pada tahun 1913 telah terjadi perpecahan di kalangan Jami'at Khair mengenai hak istimewa golongan sayyid, mereka yang tidak setuju dengan kehormatan berlebihan bagi sayyid, dikecam dan dicap sebagai reformis dan kemudian mendidrikan organisasi Jami'ah alIslam wa al-Irsyad al- Arabiyah, yang secara umum dikenal dengan alIrsyad. Al-Irsyad didirikan pad tahun 1913 dan mendapatkan pengesahan dari Belanda pada tanggal 11 Agustus $1915^{8}$.

Tokoh yang paling berperan dalam peristiwa ini adalah Syaikh Ahmad Surkati, ia mengeluarkan fatwa tentang jaiz atau sahnya pernikahan yang menjawab pertanyaan Umar bin Said Sungkar ipar awad Sungkar Al-Urmei, mengenai apakah diperbolehkan (kufu) kawin yang tidak sepadan (kafa'ah) yakni tidak sepadannya seorang "syarifah" menikah dengan seorang "non Sayyid" meski sama-sama memeluk agama Islam dan meski persyaratan lainnya sudah terpenuhi. Menurut Ahmad Surkati Hukum kafa'ah seperti yang dikenal itu sepenuhnya tesingkir di Mesir, Sudan, di Hejaz dan di negara-negara Islam lainnya ${ }^{9}$.

Ahmad Surkati tampil sebagai tokoh pemikir baru dalam masyarakat Indonesia, ia berpendapat bahwa tidak ada perbedaan diantara sesama manusia, tidak peduli ia orang Arab atau tidak, tidak peduli ia sayyid atau bukan sayyid, semua manusia sama, keturunan, harta, ataupun pangkat tidak menjadi penyebab adanya diskriminasi dalam Islam, yang membedakan adalah ketakwaan kepada Allah SWT.

Hal demikian nampak dalam kehidupan suatu masyarakat yang terkadang menjadi salah satu sumber terjadinyan perbedaan pendapat (komplik) adalah masalah stratifikasi sosial yang cukup signifikan, manusia sering terikat diri pada adanya perbedaan kedudukan. Sebab andaikan

\footnotetext{
${ }^{7}$ Lihat Dalier Noer, Op. Cit, h. 72

${ }^{8}$ Harun Asrohah, Sejarah Pendidikan Islam, (Cet.I; Jakarta : PT. Logos Wacana Ilmu, 1999), h. 161

${ }^{9}$ Lihat Hussein Badjerei, Op.Cit, h. 29
} 
mengerti tentang tujuan hidup manusia atau - boleh jadi memang mereka menganggap suatu trasdisi nenek moyangnya yang harus dipelihara dan dilaksanakan walaupun itu semua manusia berasal dari yang satu yaitu Adam - maka tidak seharusnya menjadikan status sosial sebagai alat untuk memisahkan diri dari golongan yang dianggap tidak sepadan dengannya, tetapi melainkan saling menumbuhkan rasa kasih sayang, saling membantu, menghormati bahkan menjadi tali pengikat diantara sesama makhluk khususnya sesama Muslim sebagaimana yang dicontohkan Rasulullah Saw.

Al-Irsyad sebagai perhimpunan Islam selangkah demi selangkah berkembang dengan pesat, para pengurusnya mulai mengembangkan sayapnya dibeberapa daerah dengan membuka cabang-cabang di wilayah bumi persada ini dan cabang al-Irsyad yang pertama dibuka pada tanggal 29 Agustus 1917 di Tegal selanjutnya, Pekalonghan, Bumiayu, Cirebon, lawang (Surabaya) pada tanggal 21 Januari 1919, dan sampai pada daerah Aceh khususnya Louksamawe.

\section{Bidang Pembaharuan Al-Irsyad \\ Bidang Pendidikan}

Berdirinya organisasi atau perhimpunan Al-Irsyad bukan didorong oleh keinginannya untuk mengadakan sesuatu yang baru, tetapi didasarkan atas ketaatan aqidah agama yaitu memurnikan ajaran agama Islam secara konsekwen dan murni dengan berdasar pada al-Qur'an dan Hadits.

Bahwa perhimpunan al-Irsyad merupakan lembaga yang banyak perhatiannya pada pendidikan dan untuk itu dibukalah secara resmi Madrasah yang pertama pada tanggal 15 Sawwal 1332 atau bertepatan dengan hari Ahad 6 September 1914 dengan nama Madrasah Al-Irsyad Al Islamiyah dibawah pimpinan Syaik Ahmad Surkati di rumah tempat tinggalnya ${ }^{10}$. Hal yang sangat mengagumkan bagi warga Arab khususnya dan warga pribumi Indonesia pada umumnya adalah bahwa setelah Al-Irsyad membuka cabang-cabang di beberapa kota di Indonesia para pengurus AlIrsyad dengan gigih mendirikan sekolah-sekolah yang walaupun tingkat rendah (dasar) sampai tingkat menengah.

Jakarta merupakan tempat berdirinya Al-Irsyad banyak didapatkan Sekolah Al-Irsyad yang pada umumnya lebih banyak jenisnya, sekolahsekolah tingkat dasar, sekolah guru, disamping itu ada takhassus (pelajaran

\footnotetext{
${ }^{10}$ Ibid, h. 32
} 
dua tahun), dimana para pelajar dapat mengadakan spesialisasi dalam bidang agama, pendidikan atau bahasa. ${ }^{11}$

Al-Irsyad dengan sekolah (Madrasahnya) membagi lima jenjang pendidikan yaitu:

1. Auwaliyah lama pelajaran 3 tahun (tiga kelas )

2. Ibtidaiyyah, lama pelajaran 4 tahun (empat kelas )

3. Tajhiziah, lama pelajaran 2 tahun (dua kelas )

4. Mu'allimin, lama pelajaran 4 tahun (empat kelas )

5. Takhassus, lama pelajaran 2 tahun (dua kelas $)^{12}$.

Jenjang pendidikan auwaliayah dan Ibtidaiyah merupakan tingkat pemula atau dasar, kemudian Tajhiziah merupakan tingkat lenjutan atau menengah sementara Muallimin mengarahklan murid untuk langsung mengajar sebagai asisten sedangkan Takhassus tingkat spesialisasi yang dipilih siswa. Penjenjangan tersebut seluruhnya dalam satu sekolah dan satu bangunan, ini disebabkan beragamnya siswa dilihat dari segi usia masingmasing. Siswa yang tingkat kecerdasannya tinngi dapat dipindahkan kekelas yang lebih tinggi, sehingga siswa ada yang selesai tidak sampai 15 tahun.

Lembaga pendidikan Al-Irsyad pada dasarnya mengajarkan bahasa arab sebagai mata pelajaran yang terpenting, sebagai alat untuk memahami Islam dari sumber-sumber pokoknya, buku-buku pelajaran yang berilustrasi gambar-gambar khususnya manusia telah dikenal di sekolah-sekolah, disamping itu diajarkan bahas Belanda dan olah raga ${ }^{13}$.

Kemudian pada tahun 1942 Al-Irsyad memperbaiki struktur kependidikannya siswa dengan mengeluarkan peraturan bahwa anak-anak (siswa) dibawah umur 10 tahun yang dapat diterima pada kelas satu Sekolah Dasar yaitu sekolah lima tahun jangka belajarnya, Pelajar-pelajar di sekolah guru juga mempunyai kesempatan untuk latihan mengajar, mereka yang berusia diatas 10 tahun dapat masuk ke kelas lebih tinggi tergantung pada kemampuannya dan mereka yang tinggal di asrama menerima latihan olah $\operatorname{raga}^{14}$.

Melalui sekolah-sekolah Al-Irsyad dikembangkan jalan pikiran anakanak didik dengan menekakankan pengertian dan daya kritik, tidak melulu dalam bentuk hafalan, anak tidak ditempa secara dogmatik sempit dengan

\footnotetext{
${ }^{11}$ Lihat Deliar Noer, Op.Cit, h. 75

${ }^{12}$ Mahmud Yunus, Sejarah Pendidikan Islam di Indonesia, (Cet.III; Jakarta : Mutiara Sumber Widya, 1992), h.307

${ }^{13}$ Lihat Hussein Badjerei, Op.Cit, 108

${ }^{14}$ Lihat Dalier Noer, Op.Cit, h. 77
} 
harapan mereka kelak akan bisa menjadi Mujaddid dan tidak menjadi pengikut taqlid buta, mereka para pengajar penekanan pendidikan terletak pada tauhid, fiqhi dan sejarah. Murid-murid sekolah Al-Irsyad bukan hanya dari golongan bangsa Arab dari syaikh tetapi ada juga dari golongan Alawi (sayyid) bahkan orang Indonesia pun turut mengecap pendidikan di AlIrsyad.

Dapat disimpulkan bahwa secara umum pendidikan Al-Irsyad merupakan sarana pembentukan watak, cita-cita dan kemauan serta mengarahkannya kepada ajaran yang benar seperti yang digariskan dalam Al-Qur'an dan Hadits, sehingga nampak pembaharuan yang dilakuakn AlIrsyad mempunyai arti penting sesuai dengan garis pokok konsep Muhammad Abduh.

Al-Irsyad berhasil memobilisasi kecerdasan bangsa Indonesia di bidang pendidikan tidak hanya terbatas di kalangan muslim keturunan Arab saja tetapi juga muslim warga Indonesia (penduduk pribumi) yang pada pase berikutnya banyak menyumbangkan pergerakan melawan penjajah, berbeda dengan Jami' at Khair hanya mengurusi pendidikan, ketika muhammadiayah dan Persatuan Islam lahir banyak bekerjasama dalam bidang pendidikan, sekolah sekolah yang didirikan tidak hanya di Jakarta saja melainkan meluas kewilayah diluar Jakarta bahkan diluar pulau jawa.

Perkembangan Al-Irsyad melaju dengan cepat karena pendanaan yang luar biasa dari anggotanya, ini terlihat pada kermajuan bagi murid-murid yang bersekolah di lembaga ini, mereka mendapatkan beasiswa untuk melanjutkan studinya ke tingkat yang lebih tinggi terutama ke Universitas Al-Azhar Cairo Mesir.

\section{Bidang Keagamaan}

Dalam bidang ini Al-Irsyad memperlihartkan kegigihannya untuk memurnikan ajaran Islam yang benar sesuai tuntunan Al-Qur'an as Sunnah. Menyebarkan gagasan-gagasan pembaruan lewat tabligh, pertemuanpertemuan, dan penerbitan beberapa buku dan pamplet.

Dalam menyebarluaskan paham keagamaan Al-Irsyad, telah menerbitkan majalah pertama pada bulan Muharram 1314 atau tahun 1923 yaitu Majalah Az-Zakhirah Al-Islamiyah, majalah ini terbit setiap bulan di Jakarta dalam dua edisi yaitu bahasa Arab dan bahasa Indonesia. Penerbitan majalah ini telah menggoncangkan para ulama serta santri Indonesia sebab lewat penerbitan ini telah dibongkar puluhan Hjadits palsu dan Hadits- 
Hadits yang lemah sanadnya yang sebelumnya tidak disadari oleh masysartakat muslim Indonesia. ${ }^{15}$

Hal tersebut apa yang dilakukan Syaikh Ahmad Surkati selalu dibantu oleh Syaikh Muhammad Nur Al-Anshary dan Abdullah Badjerei sebagai redaktur dalam memberantas berbagai kebiasaan masyarakat yang tidak sesuai dengan ajaran agama Islam.

Pertanyaan-pertanyaan dari seluruh penjuru tanah air Indonesia dalam hal Ushul dan Furu' agama, mempertahankan beberapa hukum ibadat dan muamalat di Indonesia dijawab Syaikh Ahmad Surkati sebagai pimpinan majalah tersebut bertentangan dengan al-Qur'an dan Sunnah Nabi Muhammad SAW seperti tawassul, tarekat-tarekat, perkara kenduri, talqin mayat dan sebagainya. ${ }^{16}$

Apa yang dilakukan tersebut sudah barang tentu para kyai dan ulama bangkit (tersentak) untuk menantang beliau, menurut G.F. Pijper persoalan ijtihad dan taklid, sunah dan bid'ah dan menziarahi makam dan memohon perantaraan (tawassul) para Nabi dan para Wali (orang-orang suci). Yang dibahas hanya berdasarkan al-Qur'an dan Hadits saja, ia berprinsip agama Islam telah sempurna dan tidak memerlukan tambahan lagi dari siapapun (Q.S. $5: 3$ )

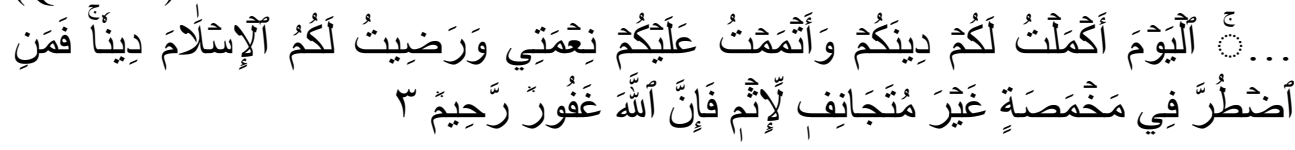

Terjemahnya : Pada hari ini telah Ku-sempurnakan untuk kamu agamamu, dan telah Ku-cukupkan kepadamu nikmat-Ku, dan telah $\mathrm{Ku}-$ ridhai Islam itu jadi agama bagimu. Maka barang siapa terpaksa karena kelaparan tanpa sengaja berbuat dosa, sesungguhnya Allah Maha Pengampun lagi Maha Penyayang

Dan segala sesuatu yang baru bid'ah dan merupakan suatu penyelewengan tidak dibenarkan menambah sesuatu kepada Syara'(hukum Islam) khususnya ibadat. Ada juga hal-hal baru yang sesungguhnya sumbernya syara' antara lain sekolah, rumah sakit, perhimpunan dengan tujuan menolong sesama manusia dan sebagainya. Perbuatan baik seperti ini termasuk hal-hal yang dianjurkan oleh hukum Islam. Bahkan perbuatan menziarahi kubur itu sebenarnya sunnah (dianjurkan oleh agama) asal dengan maksud mengingatkan diri sendiri, juga hadits tentang membaca al-

\footnotetext{
${ }^{15}$ Lihat Hussein Badjerei, Op.Cit, h.41

${ }^{16}$ Lihat Hasbullah, Op.Cit, h.133
} 
Qur'an pada waktu menziarahi makam adalah lemah daif termasuk tawassul. ${ }^{17}$

Persoalan tersebut telah melekat pada diri Ahmad Surkati bahkan secara umum Al-Irsyad dalam pembaharuan keagamaannya sehingga kebiasaankebiasaan yang dilakukan masyarakat Islam di Indonesia baik keturunan Arab maupun penduduk pribumi tidak sesuai kedua sumber agama Islam, maka mereka berusaha untuk membasminya, misalnya talkin pada waktu penguburan termasuk tahlil dirumah sesudah pemakaman begitu pula tentang perkawinan antara Syarifah dan orang yang bukan sayid atau sebaliknya.

\section{KESIMPULAN}

Al-Irsyad merupakan suatu perhimpunan (lembaga) yang muncul dari adanya segolongan umat (keturunan Arab Alawi) yang masih menganggap derajat sosialnya lebih tinggi dari golongan Arab yang bukan dari keturunan Sayyed termasuk juga merambah kejawenan di Indonesia, ini terjadi pada tubuh perhimpunan Jami'at Khaer, sehingga memunculkan sosok yang juga syaikh menentang terhadap adanya penggolongan manusia yaitu Syaikh Ahmad Surkati, beliau berpendapat bahwa manusia sama dihadapan Allah SWT tanpa membeda-bedakan suku, ras dan agama yang hanya membedakan hanyalah keimanan dan ketaqwaan kepada-Nya.

Perhimpunan Al-Irsyad lebih telah memfokuskan perhatiannya pada bidang pendidikan Islam hal ini dapat dilihat berdirinya cabang-cabang AlIrsyad di beberapa pelosok tanah air dan telah mendirikan sekolah-sekolah mulai dari tingkat dasar sampai pada tingkat menengah, berbeda dengan pondok pesanteren yang menekankan penghafalan, masalah teologi dan hukum, akan tetapi sistem pendidikan dan pengajaran mengutamakan pelajaran bahasa Arab agar murid-murid Madasah mampu memahami ajaran Islam yang koprehensif dengan baik,

Demikian pula pada bidang keagamaan, al-Irsyad telah berusaha keras untuk mengembalikan masyarakat kepada pemurnian ajaran Islam yang benar sehingga segala bentuk aktivitas hidup dan kehidupan umat Islam selalu berlandaskan pada Al-Qur'an dan Hadits yang penekanannya pada aqidah ketauhidan, guna mewujudkan pribadi Muslim dan masyarakat Islam menuju keridhoan Allah SWT. Al-Irsyad telah berhasil mengajarkan dan

\footnotetext{
${ }^{17}$ G.F. Pijper, Sejarah Islam di Indonesia 1900-1950 diterjemahkan oleh Tudjimah dan Yessy Augusdin, (Cet. II; Jakarta : Penerbit Universitas Indonesia (UI-Press, 1984), h.122-123
} 
membawa masyarakat dari muslim golongan Arab dan muslim penduduk asli Indonesia kearah pemurnian ajaran Islam baik masalah aqidah, ibadah maupun amaliah Islam sebagaimana yang diajarkan oleh Rasulullah saw.

\section{DAFTAR PUSTAKA}

Asrohah, Harun, Sejarah Pendidikan Islam, Cet.I, Jakarta, PT. Logos Wacana Ilmu, 1999

Badjerei, H. Hussein, Al- Irsyad Mengisi Sejarah Bangsa, Cet.I, Jakarta, Badan Penerbit Presto Prima Utama, 1996

Noer, Deliar, Gerakan Moderen Islam di Indonesia 1900-1942, Ed.II, Jakarta, LP3ES, 1982

Pijper, G.F., Beberapa Studi Tentang Sejarah Islam di Indonesia 1900-1950, diterjemahkan oleh Tudjimah dan Yessi Augusdin, Cet.II, Jakarta, Universitas Indonesia Press, 1985

Yatim, Badri, Sejarah Peradaban Islam, Dirasah Islamiyah II, Ed, Cet II; Jakarta, PT. Raja Grafindo Persada, 2000

Yunus, Mahmud, Sejarah Pendidikan Islam di Indonesia, Cet.III, Jakarta, Mutiara Sumber Widya, 1992

Zuhairini, dkk, Sejarah pendidikan Islam, Cet.III,Jakarta, Bumi Aksara, 1992 